\title{
Música, linguagem e videogames: um estudo sobre suas contribuições, correlações e confluências
}

\author{
Leonardo J. Porto Passos \\ José Fornari \\ Universidade Estadual de Campinas
}

\begin{abstract}
Resumo
Música e linguagem são atividades comunicacionais exclusivas e fundamentalmente humanas, que permeiam todas as áreas de atuação, inclusive as lúdicas, como é o caso dos games (videogames e audiogames). Este artigo apresenta uma pesquisa descritiva a partir de uma revisão bibliográfica do estado da arte a fim de compreender e descrever como a música - e outros sons comunicacionais não semânticos, como paisagens sonoras, efeitos sonoros etc. - e a linguagem agem e interagem na construção e no desenvolvimento narrativo dos games e quais são os recursos disponíveis para ampliar essa sinergia comunicacional com a intenção de oferecer imersão e a melhor experiência possível ao jogador e incrementar os feedbacks e a expressividade fornecida pelo game.
\end{abstract}

Palavras-chave: Videogames. Audiogames. Sonologia. Narratologia. Design de jogos.

\section{Introdução}

Os videogames - também conhecidos como jogos eletrônicos ou simplesmente games - , para fornecer informações, comunicar, narrar, proporcionar interatividade, ${ }^{1}$ ambientar, estabelecer premissas e ter expressividade, utilizam-se de diversas formas de comunicação, como textos, diálogos, imagens, vídeos, animações e sons - cada uma empregada em diferentes proporções de acordo com cada jogo -, algumas delas semânticas e outras não. E é esta relação entre linguagem² semântica $^{3}$ (que possui significados preestabelecidos) e não

\footnotetext{
1 Salen e Zimmerman (2012a, p. 75-76) apresentam "quatro modos de interatividade ou quatro diferentes níveis de engajamento que uma pessoa pode ter com um sistema interativo", a saber: Modo 1. Interatividade cognitiva; ou a participação interpretativa. Modo 2. Interatividade funcional; ou participação utilitária. Modo 3. Interatividade explícita; ou participação com as escolhas e os procedimentos definidos. Modo 4. Interatividade além do objeto; ou a participação na cultura do objeto.

2 Para a linguística, "Linguagem é a capacidade específica à espécie humana de comunicar por meio de um sistema de signos vocais (ou língua), que coloca em jogo uma técnica corporal complexa e supõe a existência de uma função simbólica e de centros nervosos geneticamente especializados" (DUBOIS et al., 2004, p. 387). Neste trabalho, por vezes o termo linguagem será utilizado em seu sentido lexical, para referir-se também a formas de comunicação não verbais, como textos e imagens, por exemplo. Assim, linguagem será tratada como "qualquer meio sistemático de comunicar ideias ou sentimentos através de signos convencionais, sonoros, gráficos, gestuais etc. Qualquer sistema de símbolos ou sinais ou objetos instituídos como signos; código" (HOUAISS, 2009, verbete "linguagem").

${ }^{3}$ Num sistema linguístico, o componente do sentido das palavras e da interpretação das sentenças e dos enunciados. Ou ainda, a teoria abstrata da significação ou da relação entre os signos e seus referentes (HOUAISS, 2009, verbete "semântica"). A semântica busca "compreender como o ser humano elabora representações simbólicas do mundo,
} 
semântica (sem significados preestabelecidos, de ordem mais expressivo-subjetiva) que nos interessa no presente estudo, especificamente a relação entre música e narrativa e como ambas podem atuar de forma sinérgica em prol da expressividade artística, da imersão ${ }^{4}$ do jogador e de uma experiência relevante, permeada pela interação lúdica significativa. ${ }^{5}$ Toda a análise será embasada por estudos em sonologia, ${ }^{6}$ narratologia ${ }^{7}$ e design de jogos. ${ }^{8}$

Trata-se de uma pesquisa descritiva com procedimentos bibliográficos que unem a área da linguagem, cinema, games e sonologia, que visa apontar e caracterizar os usos e as funções dos sons nos games e de que modo esses recursos sonoros fornecem informações que podem influenciar nas decisões do jogador e como operam em paralelo à narrativa.

de que modo as organiza e estrutura, de acordo com princípios capazes de estabelecerem a aceitabilidade e a coerência dessas representações simbólicas, objetivas e subjetivas, de dados da realidade" (MARQUES, 2003, p. 16). Tomaremos, portanto, neste trabalho, o sentido amplo de semântica como o estudo do significado em linguagem, do sentido dos elementos formais da língua, da significação das formas linguísticas (MARQUES, 2003, p. 15). Por extensão de sentido, usaremos linguagem semântica com o sentido de "linguagem com significados objetivos", em oposição a comunicação não semântica, ou seja, "comunicação expressivo-subjetiva".

4 "A experiência de ser transportado para um lugar primorosamente simulado é prazerosa em si mesma, independentemente do conteúdo da fantasia. Referimo-nos a essa experiência como imersão. "Imersão" é um termo metafórico derivado da experiência física de estar submerso na água. Buscamos de uma experiência psicologicamente imersiva a mesma impressão que obtemos num mergulho no oceano ou numa piscina: a sensação de estarmos envolvidos por uma realidade completamente estranha, tão diferente quanto a água e o ar, que se apodera de toda a nossa atenção, de todo o nosso sistema sensorial. Gostamos de sair de nosso mundo familiar, do sentido de vigilância que advém de estarmos nesse lugar novo, e do deleite que é aprendermos a nos movimentar dentro dele" (MURRAY, 2003, p. 102).

5 "A interação lúdica significativa em um jogo surge da relação entre a ação do jogador e o desfecho do sistema; é o processo pelo qual um jogador toma medidas no sistema projetado de um jogo e o sistema responde à ação. O significado de uma ação em um jogo reside na relação entre ação e resultado. [...] A interação lúdica significativa ocorre quando as relações entre ações e resultados em um jogo são discerníveis e integradas no contexto maior do jogo. Criar uma interação lúdica significativa é o objetivo do design de jogos bem-sucedido" (SALEN; ZIMMERMAN, 2012a, p. 49-50).

6 A sonologia é "voltada para aspectos mais tecnicistas da produção musical (música eletroacústica, desenvolvimento e aplicação de novas técnicas e tecnologias à música, computação aplicada à música, acústica musical e psicoacústica) [...] abarcando tanto o estudo crítico, analítico e reflexivo a respeito das práticas sonoras quanto se envolvendo com os aspectos criativos dessas práticas" (IAZZETTA, 2014, p. 1).

7 "A narratologia é uma disciplina teórica com amplo desenvolvimento operatório, genericamente centrada na narrativa enquanto modo de representação literária e não literária, bem como na análise de textos narrativos de diferentes naturezas, em variados contextos. Isto significa que a narratologia não tem como objeto apenas os textos narrativos literários, nem tão-só os textos narrativos verbais; no centro da sua atenção encontra-se o fenômeno da narratividade, como propriedade que permite distinguir as narrativas enquanto tais. [...] A narratologia recorre ao suporte epistemológico da teoria e da análise semiótica, tal como se estabeleceram no século XX, a partir de contributos variados, com destaque para a linguística saussuriana, para a filosofia da linguagem peirciana, para o formalismo russo e para o estruturalismo linguístico e literário. Foi no âmbito deste último que, em 1969, Tzvetan Todorov usou, provavelmente pela primeira vez, o termo narratologia, para designar 'uma ciência que ainda não existe, digamos, a narratologia, a ciência da narrativa"' (REIS, 2018, p. 333).

8 O design de jogos é o campo de atuação do designer de jogos, "[...] um tipo particular de designer, muito semelhante a um designer gráfico, designer industrial ou arquiteto. Um designer de jogos não é necessariamente um programador, um designer visual ou gerente de projeto, embora às vezes também possa desempenhar essas funções na criação de um jogo. O designer de jogos pode trabalhar sozinho ou em uma grande equipe. O designer de jogos pode criar jogos de cartas, jogos sociais, videogames ou qualquer outro tipo de jogo. O foco do designer de jogos é projetar a jogabilidade (gameplay), concebendo e elaborando regras e estruturas que resultam em uma experiência para jogadores. Assim, o design de jogos, como disciplina, requer um foco nos jogos em si e por si próprios. Em vez de colocar os jogos a serviço de outro campo, como a sociologia, a crítica literária ou a ciência da computação, nosso objetivo é estudar os jogos dentro de seu próprio espaço disciplinar. Como o design de jogos é uma disciplina emergente, muitas vezes nos apropriamos de ideias e conceitos de outras áreas de conhecimento - da matemática e ciência cognitiva; da semiótica e estudos culturais. Podemos não nos apropriar da forma mais ortodoxa, mas fazemos isso com o intuito de ajudar a estabelecer um campo adequado de design de jogos" (SALEN; ZIMMERMAN, 2012a, p. 19). 


\section{Definição de jogo e videogame}

Para evitarmos equívocos lexicais e tratarmos cada termo de maneira apropriada, vamos buscar definir o que são jogos e o que são videogames para que possamos elencar os elementos constituintes de um jogo e distinguir o que é e o que não é um game.

Como o substantivo jogo e o verbo jogar são utilizados em diversas acepções na língua portuguesa (“jogar fora”, “o jogo da vida”, “jogo da sedução”, “jogar búzios”, “jogo de cena”, "jogo de cintura", "jogo de palavras", “jogo duplo", "abrir o jogo", "esconder o jogo" etc.), vamos definir formalmente o que é jogo e o que é videogame.

Jesse Schell (2011, p. 34), designer de jogos e autor do livro A Arte de Game Design (The Art of Game Design: a book of lenses), parte do levantamento de 10 atributos para chegar a uma definição de jogo (qualquer jogo, não apenas videogames). O autor estabelece que jogos (1) são jogados voluntariamente, (2) têm objetivos, (3) têm conflitos, (4) têm regras, (5) podem levar à derrota ou vitória, (6) são interativos, (7) têm desafios, (8) podem criar valores internos próprios, (9) envolvem os jogadores e (10) são sistemas fechados, formais.

A partir desta lista de atributos, Schell (2011, p. 37) chega à sucinta definição: "Um jogo é uma atividade de solução de problemas, encarada de forma lúdica".

O autor também defende que qualquer jogo, eletrônico ou não, é formado por quatro elementos básicos (SCHELL, 2011, p. 41-42): 1) mecânicas, os procedimentos e regras; 2) narrativa, a história, a sequência de eventos; 3) estética, a aparência e as sensações proporcionadas ou sugeridas; e 4) tecnologia, materiais e interações que tornam o jogo possível, sejam elas eletrônicas e sofisticadas (computadores, consoles ${ }^{9}$ ) ou não (papel, lápis, dados hexagonais etc.).

Já de acordo com o designer de jogos Scott Rogers (2012, p. 26-27), um jogo é uma atividade que (1) requer no mínimo um jogador, (2) tem regras e (3) tem uma condição de vitória. E um videogame, por conseguinte, é um jogo disponibilizado em uma tela de vídeo.

Katie Salen e Eric Zimmerman (2012a, p. 95), após analisarem definições de diversos designers de jogos e estudiosos do tema, chegam à seguinte definição: "Um jogo é um sistema no qual os jogadores se envolvem em um conflito artificial, definido por regras, que implica um resultado quantificável".

Para estes autores, existem quatro características que definem os jogos digitais: (1) interatividade imediata e restrita, (2) manipulação da informação, (3) sistemas complexos e automatizados e (4) comunicação em rede (SALEN; ZIMMERMAN, 2012a, p. 107).

\footnotetext{
9 "A console game is a type of interactive multimedia software that uses a video game console to provide an interactive multimedia experience via a television of other display device. The game console generally consists of a handheld control device (although some use cameras to monitor user movements) and a computer that runs the game's software. A console game is also known as video game." (CONSOLE..., 2021).
} 
Em uma definição curta e simples, porém bastante elucidativa, Nicolas Esposito (2005, $\mathrm{s} / \mathrm{p}$ ) defende que um videogame é um jogo que jogamos por meio de um aparato audiovisual e que pode ser baseado em uma história.

No Dicionário Houaiss (2009, verbete “video game") estão disponíveis as seguintes definições para videogame: (1) jogo em que se manipulam eletronicamente imagens numa tela de televisão; (2) todo jogo em que se usa um microcomputador equipado de teclado ou console para tomar decisões, reagir a ações, manipular mudanças ou responder a perguntas que apareçam na tela; e (3) equipamento, independente ou ligado a computador, específico para jogos desse tipo.

Portanto, com base nas definições apresentadas, consideramos aqui videogame como um jogo eletrônico com o qual jogador(es) interage $(\mathrm{m})$ por meio de um periférico (interface de usuário ou dispositivo de entrada) conectado ao aparelho (no caso dos computadores ou consoles) ou que faça parte dele (caso dos arcades $^{10}$ ), como um controle (joystick ${ }^{11}$ ou gamepad ${ }^{12}$ ), teclado, mouse ou tela sensível ao toque, para gerar feedback visual ao jogador por meio de uma tela e/ou por sons emitidos por alto-falante.

Para além desta definição geral, é relevante mencionar que existem diversos tipos de videogames, categorizados de acordo com o tipo de plataforma para a qual o jogo é desenvolvido e, consequentemente, com o tipo de feedback visual que será oferecido ao jogador: PC games (personal computer games, jogos para computador, jogados por meio de um monitor), console games (aparelhos conectados a televisores, que no Brasil são também chamados de videogames, com Playstation, Xbox, Wii, entre outros), mobile games (jogos para dispositivos móveis, como celulares, smartphones e tablets, com telas reduzidas e geralmente sensíveis ao toque), arcade games (máquinas geralmente da altura de uma pessoa adulta, que possuem um monitor acoplado, são operadas a partir da introdução de moedas ou fichas, e como costumam ser disponibilizadas em locais específicos abertos ao público, os jogos geralmente são mais curtos para possibilitar maior rotatividade de jogadores)

\footnotetext{
10 "An arcade game is a game machine typically found in public places like malls, restaurants and amusement arcades, and is usually coin operated. Arcade games are usually video games, pinball machines or electromechanical games. The late 1970s through the 1980s was the golden age of the arcade games. They enjoyed some relative popularity even during the early 1990s. The popularity of this platform slowly declined, however, as console and PC games came into prominence." (ARCADE..., 2021).

11 "A joystick is an input device that can be used for controlling the movement of the cursor or a pointer in a computer device. The pointer/cursor movement is controlled by maneuvering a lever on the joystick. The input device is mostly used for gaming applications and, sometimes, in graphics applications. A joystick also can be helpful as an input device for people with movement disabilities." (JOYSTICK, 2021).

12 "A gamepad, also sometimes called joypad, refers to an input device used for gaming purposes. It is a video game controller that can be held with both hands and has multiple buttons on it to be pressed by the thumbs. Gamepads were first introduced with gaming console systems as a peripheral device to connect the user with the system." (GAMEPAD, 2021).
} 
e VR games (virtual reality games, videogames de realidade virtual, ${ }^{13}$ jogados com óculos estereoscópicos especiais para esta finalidade, que possuem pequenas telas que ampliam o sentimento de presença do jogador em um ambiente virtual).

É possível notar que o feedback visual é de grande relevância para os videogames. Não à toa, a palavra vídeo é um componente morfológico da palavra videogame. Ou seja, a existência de um vídeo determina toda uma classe de jogos: os videogames. E ainda que os videogames não sejam compostos apenas por recursos visuais (como iremos tratar na próxima seção, Multimídia com várias linguagens) - e que existem games sem recursos visuais, como veremos mais à frente -, é a esses recursos visuais que se dá mais relevância, tanto por parte da indústria quanto por parte do público.

Busquemos compreender, então, qual seria a razão para tal ênfase do componente "vídeo" dos games, ou seja, para os recursos visuais, já que o áudio, a narrativa e as mecânicas são elementos igualmente constitutivos dos videogames.

\section{Predominância da visualidade}

O filósofo e sociólogo alemão Theodor Adorno (2002) cunhou o termo indústria cultural para se referir à falsa identidade do universal e do particular, justificando que toda cultura de massas dos países capitalistas é idêntica, que cinema e rádio não têm mais necessidade de serem reconhecidos como arte, são apenas negócios, indústria, sem qualquer necessidade social real. A justificativa para essa tal indústria seriam os números, sejam de consumidores (já que, na indústria cultural, tudo passa a ser produto), de faturamento, de reproduções. E a bandeira levantada por essa indústria cultural é a uniformidade, o lugar-comum, a banalização: "Os clichês seriam causados pelas necessidades dos consumidores: por isso seriam aceitos sem oposição" (ADORNO, 2002, p. 9). E obviamente, os videogames não estariam de fora dessa indústria cultural. Não é mero acaso que tanto se fale em "indústria dos games".

Como efeito de seu rápido e avançado desenvolvimento gráfico, os games incorrem àquilo que Jean Baudrillard (1991, p. 8) chama de simulacro: "Hoje a abstração já não é a do mapa, do duplo, do espelho ou do conceito. A simulação já não é a simulação de um território, de um ser referencial, de uma substância. É a geração pelos modelos de um real sem origem nem realidade: hiper-real". Hiper-real no sentido de idealizado, um real mais perfeito que 0 próprio real, distante de seu modelo, e também do imaginário. A "simulação" de algo que nunca existiu de fato. E a problemática reside no fato de que os simuladores buscam, de acordo com o filósofo, fazer com que o real coincida com seus modelos de simulação, e por consequência, o encanto da abstração se dilui, desaparece. A simulação se opõe à

\footnotetext{
${ }^{13}$ Realidade virtual é "uma imersiva e interativa experiência que se baseia em imagens gráficas 3D geradas por computador em tempo real, em outras palavras, é uma simulação de um mundo real, ou apenas imaginário gerada por computador". (RODRIGUES; PORTO, 2013, p. 99).
} 
representação, pois ela nega o signo enquanto valor. $O$ simulacro distorce o real e se confunde com ele. É como o reality show, que busca filmar seus participantes como se as câmeras não estivessem lá, uma "Fórmula absurda, paradoxal - nem verdadeira, nem falsa: utópica” (BAUDRILLARD, 1991, p. 40).

As elucubrações de Baudrillard convergem com a teoria da sociedade do espetáculo de Guy Debord (1997), que alega que as sociedades modernas são um acúmulo de espetáculos, e que tudo o que antes era vivido diretamente se tornou representação. "A realidade considerada parcialmente apresenta-se em sua própria unidade geral como um pseudomundo à parte, objeto de mera contemplação" (DEBORD, 1997, p. 13). O espetáculo é a própria sociedade, assim como também é parte dela e unifica ambas. Todos os olhares são voltados a ele, de forma iludida, com uma falsa consciência, e sua unificação é a separação generalizada. É uma relação social mediada por imagens, âmago do irrealismo da sociedade real que se constitui como modelo de vida. "A linguagem do espetáculo é constituída de sinais da produção reinante, que são ao mesmo tempo a finalidade última dessa produção" (DEBORD, 1997, p. 15). E este mundo transformado e inundado por imagens passa a tomá-las como reais e apresentar um comportamento hipnótico, e assim, como já não é mais possível tocar diretamente, a visão passa a ser o sentido privilegiado. O que propiciou o desenvolvimento e o crescimento sem precedentes de toda uma classe de jogos baseada em vídeo: videogames.

Seriam essas as motivações para a sublimação dos aspectos gráficos - e o que parece ser uma obsessão da indústria dos games com o hiper-realismo - em detrimento do áudio e da narrativa nos videogames? Nesse sentido, recorremos ao etnomusicólogo Tiago de Oliveira Pinto:

A sensação de ouvir foi, durante séculos, dominada pela percepção visual. Mesmo que pesquisas científicas mais recentes tenham recuperado este sentido enquanto seus aspectos físico, cultural e mesmo social, discursos analíticos no campo da antropologia permanecem centrados no imagético e são poucos aqueles que contrapõem a discussão sobre o som à predominância da visualidade nas ciências humanas e sociais. (PINTO, 2001, p. 222).

Esta "predominância da visualidade" também pode ser vista na indústria dos videogames, que tende para o simulacro do real como recurso sedutor de um espetáculo comercial, produto de uma indústria cultural homogeneizante. Não é à toa que tanto se investe na evolução dos recursos gráficos nos videogames e em tecnologias de realidade virtual, intimamente ligadas com o hiper-real de Baudrillard. Assim - sem deixar de levar em conta a pluralidade de gêneros de games, em que alguns dão ênfase, por exemplo, à narrativa (RPGs), outros aos aspectos visuais (esportes) -, não são raros os casos em que a distribuição orçamentária acaba privilegiando os recursos gráficos em detrimento do roteiro 
(games com ótima qualidade gráfica e narrativas triviais), da jogabilidade ${ }^{14}$ (games bonitos, mas tediosos de se jogar) e do áudio (músicas e efeitos sonoros que sequer se equiparam em qualidade com os gráficos, chegando até a causar estranhamento pela discrepância).

\section{Desenvolvimento em diversas linguagens}

Ao longo de seu desenvolvimento, os videogames tiveram sua linguagem construída a partir de diversas fontes, como jogos de tabuleiro, esportes, cinema, televisão, desenhos animados, literatura, histórias em quadrinhos etc. (LUZ, 2010). Mas isso não se deu por mera apropriação. Há motivos para que os games tenham feito, e ainda façam, uso de elementos e linguagens de outras mídias em seu desenvolvimento e estruturação midiática, já que "O desenvolvimento da linguagem de qualquer mídia usa do 'empréstimo' de elementos semânticos, estruturais e sintáticos de outras mídias já estabelecidas para criar conforto psicológico e algum referencial para a nova mídia" (LUZ, 2010, p. 114). Assim como a televisão tomou de empréstimo elementos das linguagens do teatro e do rádio em sua gênese, o videogame fez uso de elementos de "outras formas de expressão enquanto construía a sua própria linguagem, absorvendo e transformando os elementos e estruturas das outras formas de mídia" (LUZ, 2010, p. 116).

Por conta de suas variadas influências e de sua característica multiforme, o videogame pode ser classificado como multimídia, e por que não dizer, "multilinguagem". Porém, por conta de sua existência recente e da consequente ausência de um campo próprio de estudo e discussão, é necessário que se recorra a áreas do saber humano já consagradas para efetivar análises aprofundadas, conforme aponta Alan Richard da Luz:

[...] o campo de estudo do vídeo game é multidisciplinar e pode acomodar diversos tipos de abordagens, seja pela ótica do cinema, teorias de televisão, semiótica, performance, literatura, narratologia, ciência da computação, comunicação, estética etc., devendo ser encarado seriamente como qualquer meio de comunicação. (LUZ, 2010, p. 17).

Neste estudo, além da incipiente área do Design de Jogos, faremos uso de conceitos das áreas de Letras (teoria da narrativa), Audiovisual (cinema) e Música (sonologia), sempre com a preocupação de analisar os games como uma mídia multilinguagem com características próprias (interatividade, não linearidade), sem incorrer ao erro de ignorar essas singularidades, o que acontece, por exemplo, quando se analisam trilhas sonoras de games tal como se fossem feitas para o cinema, pois há grandes distinções entre ambas as mídias,

\footnotetext{
14 Tomamos aqui "jogabilidade" com o significado do termo em inglês "gameplay", e não como "playability". Mas vale destacar as diferenças entre ambos: gameplay equivale a fluxo do jogo, que ocorre por meio da interação em função de mecânicas e regras do jogo; já playability corresponde à facilidade de jogar o jogo, à qualidade do jogo e à experiência do usuário, ou seja, à usabilidade (AGUIAR; BATTAIOLA, 2016, p. 537).
} 
ainda que seja comum, e compreensível, a utilização de recursos cinematográficos nos games, conforme exemplificam Salen e Zimmerman:

O jogo [Silent Hill] utiliza técnicas narrativas cinemáticas para ter um bom efeito, ligando-as intrinsecamente ao sistema do jogo e à interação do jogador: os inimigos são revelados primeiro no som, em seguida, no visual, depois por meio da interação de combate. Os efeitos sonoros gratuitos e "assustadores" podem se desgastar rapidamente, mas quando esses efeitos significarem os eventos futuros do jogo, 0 jogador irá sentar-se e prestar atenção. (SALEN; ZIMMERMAN, 2012b, p 125).

E da mesma forma que se configura um equívoco tratar o áudio de um game da mesma forma que se faz no cinema - o que pode prejudicar a imersão do jogador pelo excesso de repetição das músicas e por não levar em conta o potencial do áudio em uma mídia interativa (CAMARGO, 2018, p. 6) -, o mesmo se aplica em relação à narrativa, como aponta Jesper Juul:

Usando outras mídias como pontos de partida, podemos aprender muitas coisas sobre a construção de mundos fictícios, personagens... Mas confiar demais nas teorias existentes nos fará esquecer o que torna os jogos jogos: regras, objetivos, ações do jogador, a projeção das ações do jogador no mundo do jogo, a forma como o jogo define as possíveis ações do jogador. São as partes únicas que precisamos estudar agora. (JUUL, 2001, p. 10). ${ }^{15}$

\section{Narrativa nos videogames}

Não consideramos aqui a narrativa como pré-requisito para a definição de videogame porque há muitos jogos digitais que são totalmente abstratos e não contam nenhuma história, nem sequer apresentam personagens, como é o caso do famoso quebra-cabeça Tetris (1984) e diversos outros games.

Isso vai na contramão do que alega Janet Murray (2004, p. 1): "Os jogos são sempre histórias, até mesmo jogos abstratos como damas ou Tetris, que são sobre ganhar e perder, colocando o jogador como o herói que luta contra oponentes ou que luta pelo ambiente". ${ }^{16}$ Possivelmente a autora defende essa postura por conta de seu posicionamento em relação à hierarquia entre narrativa e as mecânicas de jogo em um game: "O que vem primeiro, a história ou o jogo? Para mim, é sempre a história que vem primeiro, porque contar histórias é uma atividade humana central, que levamos para todos

\footnotetext{
15 "Using other media as starting points, we may learn many things about the construction of fictive worlds, characters... but relying too heavily on existing theories will make us forget what makes games games: Such as rules, goals, player activity, the projection of the player's actions into the game world, the way the game defines the possible actions of the player. It is the unique parts that we need to study now."

16 "Games are always stories, even abstract games such as checkers or Tetris, which are about winning and losing, casting the player as the opponent-battling or environment-battling hero."
} 
os meios de expressão, desde as poesias improvisadas da tradição oral até a multimídia digital"17 (MURRAY, 2004, p. 2).

Ainda sobre a questão de todo jogo ser narrativo, sem exceção, como defende Murray, temos que levar em conta as introduções narrativas ou histórias pregressas (back-story), ${ }^{18}$ que "[...] posicionam o jogador no contexto de uma história maior; a ação de um jogador em um jogo é o meio pelo qual a história mais ampla é percebida. [...] Esse texto fornece um contexto narrativo no qual o jogador age [...]" (SALEN; ZIMMERMAN, 2012b, p. 102). Mas e no caso de jogos abstratos que não possuem história pregressa (como dominó, jogo da velha e o já mencionado Tetris), ou que possuem, mas são ignoradas pelo jogador? A partir do momento que um jogador interage com um game abstrato que não possui história pregressa, ou então quando o jogador desconhece por completo essa história pregressa, então o jogo passa a ser realmente abstrato, sem qualquer história ou narrativa, já que o jogo em si não contempla elementos narrativos, como personagens, universo ficcional, enredo etc., ou seja, e "Apesar de suas ações [do jogador] certamente terem um significado interativo [...], falta um contexto experimental concebido no qual esses significados mais formais são estruturados como uma história" (SALEN; ZIMMERMAN, 2012b, p. 102).

Porém, o que nos interessa aqui são justamente os videogames narrativos, cuja ênfase recai sobre a história, ou games em que a narrativa pelo menos desempenha um papel importante, não servindo apenas de "cosmético" para atrair a atenção dos consumidores. $O$ que nos importa nos games não são os números em termos de venda ou sua popularidade na indústria do entretenimento, mas seu potencial narrativo e artístico enquanto mídia, ou seja, sua capacidade de enternecer, levar à reflexão, divertir pela criatividade, sem o uso abusivo de clichês e estereótipos com propósito único de propiciar mais rendimentos financeiros.

E o que seria exatamente uma narrativa?

[...] narrativa é a representação de um mundo possível, centrada em entidades antropomórficas (designadamente, personagens) e ancorada em coordenadas temporais e espaciais que orientam certas ações para um final. [...] a representação narrativa não está vinculada apenas à linguagem verbal, podendo processar-se pelo recurso a uma pluralidade de suportes e meios (linguísticos, visuais, auditivos, corporais, eletrônicos etc.), de forma singular ou conjugada. (REIS, 2018, p. 305).

Com base na definição proposta por Carlos Reis, podemos, então, sintetizar que uma narrativa possui cinco elementos essenciais: os (1) acontecimentos, sem os quais não é

\footnotetext{
17 "Which comes first, the story or the game? For me, it is always the story that comes first, because storytelling is a core human activity, one we take into every medium of expression, from the oral-formulaic to the digital multimedia."

18 "[...] most games have a story written on the package, in the manual, or in intro-sequences, placing the player's playing in the context of a larger story (back-story), and/or creating an ideal story that the player has to realize" (JUUL, 2001, p. 2).
} 
possível contar uma história; os (2) personagens, aqueles que vivem os acontecimentos em (3) tempos e (4) espaços determinados; além de um (5) narrador, que é quem transmite a história e faz a mediação entre ela e o leitor, espectador ou jogador.

$E$ ainda podemos estabelecer em tópicos sucintos os elementos constitutivos de uma narrativa (REIS; LOPES, 1988), de modo a criar uma espécie de "guia" para o auxílio referencial da estruturação de uma história:

Quadro 1 - Elementos estruturais de narrativa

\begin{tabular}{|c|c|c|}
\hline \multicolumn{3}{|c|}{ Elementos estruturais de narrativa } \\
\hline Plano da História & Plano do Discurso & Plano da Narração \\
\hline $\begin{array}{l}\text { Personagem e as suas } \\
\text { modulações de relevo, } \\
\text { composição e caracterização: } \\
\text { - Protagonista } \\
\text { - Antagonista } \\
\text { - Coadjuvante } \\
\text { - Figurante }\end{array}$ & $\begin{array}{l}\text { Tempo do discurso, } \\
\text { virtualidades de tratamento em } \\
\text { termos de ordenação, } \\
\text { velocidade narrativa etc.: } \\
\text { - Linear } \\
\text { - Não linear } \\
\text { - Anisocronia } \\
\text { - Isocronia } \\
\text { - Analepse } \\
\text { - Prolepse } \\
\text { - Cena dialogada } \\
\text { - Pausa descritiva } \\
\text { - Etc. }\end{array}$ & $\begin{array}{l}\text { Tempo da narrativa (tempo } \\
\text { da história e tempo do } \\
\text { discurso): } \\
\text { - Anterior } \\
\text { - Intercalada } \\
\text { - Simultânea } \\
\text { - Ulterior }\end{array}$ \\
\hline $\begin{array}{l}\text { Espaço e os seus diversos } \\
\text { modos de existência: } \\
\text { - Físico } \\
\text { - Social } \\
\text { - Psicológico }\end{array}$ & $\begin{array}{l}\text { Perspectiva narrativa, a } \\
\text { quantidade e a qualidade da } \\
\text { informação diegética } \\
\text { veiculada: } \\
\text { - Focalização onisciente } \\
\text { - Focalização interna } \\
\text { - Focalização externa }\end{array}$ & $\begin{array}{l}\text { Nível narrativo: } \\
\text { - Extradiegético } \\
\text { - Intradiegético } \\
\text { - Hipodiegético }\end{array}$ \\
\hline $\begin{array}{l}\text { Ação e as suas variedades } \\
\text { compositivas: } \\
\text { - Introdução } \\
\text { - Desenvolvimento } \\
\text { - Clímax } \\
\text { - Desfecho }\end{array}$ & - & $\begin{array}{l}\text { Narrador: } \\
\text { - Heterodiegético } \\
\text { - Homodiegético } \\
\text { - Autodiegético }\end{array}$ \\
\hline
\end{tabular}

Fonte: baseado em Reis e Lopes (1988)

O ato de narrar histórias praticamente surgiu junto com a humanidade. É uma prática que irrompe épocas, fronteiras, culturas, nações. Em todos os lugares do globo se contam histórias, e é assim desde que o ser humano começou a deixar seus primeiros registros pictográficos em paredes de cavernas, ou talvez até antes disso. As narrações se 
desenvolveram junto com a humanidade e passaram a ganhar cada vez mais relevância social, cultural e artística. Tornaram-se matéria de estudos aprofundados e são parte constituinte em diversos contextos e em variados propósitos comunicativos: artísticos, informativos, conversacionais, científicos, políticos, religiosos etc. (REIS, 2018, p. 305). E é claro, nos videogames.

De acordo com o mitólogo Joseph Campbell (1995), as narrativas são estruturadas com base em padrões antigos, que foram se instituindo na cultura humana desde os primórdios de nossa existência, conceito este que o autor chamou de monomito. ${ }^{19}$ Independentemente do grau de plausibilidade das teorias de Campbell, fato é que os padrões do monomito extrapolaram a mitologia e são utilizados amplamente em diversas narrativas contemporâneas, inclusive sendo adotados como modelo de sucesso comercial pela indústria do entretenimento, como a do cinema, dos quadrinhos e dos games.

Mas qual seria a grande motivação humana para a narrativa? Por que essa prática permeia nossa vida desde sempre e não perde sua relevância em todas as culturas? Murray defende que:

\begin{abstract}
A narrativa também é uma experiência liminar. [...] todas as experiências sustentáveis de faz de conta, desde os jogos infantis até as peças de Shakespeare, evocam os mesmos sentimentos mágicos que o primeiro ursinho de pelúcia de um bebê, pois são "objetos transicionais". O urso de pelúcia oferece aconchego porque a criança projeta nele suas memórias da mãe tranquilizadora e sua percepção de si mesmo como um ser pequenino que pode ser acariciado e abraçado. [...] Uma boa história tem a mesma função para os adultos, oferecendo-nos a segurança de alguma coisa exterior a nós mesmos (pois foi criada por uma outra pessoa) sobre a qual podemos projetar nossos sentimentos. As histórias evocam nossos desejos e medos mais profundos porque fazem parte dessa mágica região de fronteira. (MURRAY, 2003, p. 103).
\end{abstract}

Nos games, assim como nos jogos de modo geral, a narrativa é amplamente utilizada ainda que alguns jogos possuam pouco viés narrativo -, entre outros motivos, com o propósito de aumentar a imersão do jogador. Mas é certo que não basta apenas seguir à risca a jornada do herói de Campbell ou os elementos apresentados no Quadro 1 para que se tenha sucesso com a imersão do jogador. Murray defende que,

[...] Para sustentar tão poderoso transe imersivo, portanto, temos de fazer algo inerentemente paradoxal: precisamos manter o mundo virtual "real" fazendo com que ele permaneça "fora dali". Precisamos mantê-lo em perfeito equilíbrio no limiar

\footnotetext{
${ }^{19}$ Campbell defendia a ideia da ubiquidade do monomito, ou jornada do herói, um padrão narrativo que sustenta a criação de todas as mitologias (e por conseguinte, as religiões), uma estrutura que é compartilhada por muitas das mais notórias narrativas de todos os tempos. É possível, inclusive, estabelecer um paralelo entre o monomito, a teoria da monogênese linguística (ou proto-linguagem humana) - que alega que todas as línguas faladas humanas têm uma mesma origem, e por isso a semelhança fonética entre palavras de mesmo significado em culturas totalmente distintas - e a monogênese musical, hipótese levantada por Leonard Bernstein (The Unanswered Question: Lecture 1, "Musical Phonology", 1973) sobre uma origem comum para a música.
} 
do encantamento, sem deixar que ele desmorone para um lado ou para outro. (MURRAY, 2003, p. 103).

É possível que esteja neste afã, por parte da indústria dos videogames, em "manter o mundo virtual 'real'” o problema do simulacro, do hiper-real, apontado por Baudrillard, conforme discutido na seção Predominância da visualidade.

Mas independentemente da busca incessante pela imersão, pelo "hiper-real" ou qualquer outro motivo que justifique a utilização de narrativas nos games, faz-se necessário compreender que, por se tratar de uma mídia interativa - e portanto, não linear -, multilinguagem e dotada de características próprias, a narrativa nos games deve ser pensada de forma única, com vias a explorar essas singularidades para a obtenção de narrativas inovadoras e adequadas às características próprias dos games, pois "[...] é a estrutura dinâmica dos jogos, a sua complexidade emergente, seus mecanismos participativos, seus ritmos e padrões experimentais que são o segredo para entender como os jogos constroem experiências narrativas" (SALEN; ZIMMERMAN, 2012b, p. 105).

Para que as narrativas nos videogames possam alcançar seu apogeu de expressividade artística e inovação, é imprescindível que modelos de sucesso comercial sejam quebrados para que se saia, enfim, do lugar-comum a que muitos jogos são relegados por conta da contínua manutenção do estabelecido da indústria em busca de sucesso comercial. Privilegia-se o apuro visual e o ritmo frenético de interação em detrimento da elaboração narrativa, conforme bem expressa Murray:

Muito [...] empenho foi dedicado ao desenvolvimento de ambientes visuais mais elaborados e de tempos de reação mais rápidos, avanços que proporcionaram aos jogadores desafios mais variados à sua rapidez no gatilho contra oponentes visualmente mais convincentes. O conteúdo narrativo desses jogos é escasso, sendo frequentemente emprestado de outros meios ou suprido por personagens esquemáticos e estereotipados. Essa falta de profundidade narrativa faz com que mesmo personagens bastante populares [...] não consigam repetir seu sucesso como heróis nas telas de cinema. (MURRAY, 2003, p. 61).

Essa padronização estereotipada e repetida à exaustão é típica da indústria cultural nas várias formas de construção narrativa, já que o produto final, em última instância, é o lucro, e não os games, e a justificativa para a repetição incessante de modelos bem-sucedidos é a segurança financeira diante dos altos investimentos.

Para que seja possível explorar os recursos narrativos de um game em toda a sua extensão, tendo em vista as peculiaridades da mídia, é necessário entender como a narrativa funciona neste meio multilinguagens. Primeiro precisamos definir as duas formas possíveis de narrativa em um videogame: a incorporada e a emergente.

A narrativa incorporada é o conteúdo da narrativa gerado previamente, que existe antes da interação de um jogador com o jogo. Projetada para proporcionar 
motivação para os eventos e as ações do jogo, os jogadores experimentam a narrativa incorporada como um contexto da história. [...] ela é experimentada por meio da interação do jogador, mas existe formalmente separada dele. [...] A narrativa incorporada também fornece 0 arco dramático principal para 0 jogo, estruturando a interação de um jogador e o movimento por meio do mundo do jogo de uma forma significativa. Os elementos narrativos incorporados tendem a lembrar os tipos de experiência narrativa que a mídia linear fornece. [...] podem assumir uma variedade de formas e ser alcançados por diversos meios, mas, independentemente de como eles são experimentados, os elementos narrativos incorporados são unidades fixas e predeterminadas de conteúdo narrativo [...]. (SALEN; ZIMMERMAN, 2012b, p. 105).

As narrativas incorporadas são construídas por elementos criados pelos designers de jogos para servirem como estrutura para a interação. São histórias, elementares ou complexas, entregues ao jogador antes ou durante o jogo e funcionam de forma semelhante às mídias lineares: são predeterminadas e imutáveis.

Já as narrativas emergentes surgem da forma como o jogador interage - de maneira deliberada ou espontânea - com o sistema de jogo, e a partir daí, surge uma experiência narrativa única para cada jogador:

\begin{abstract}
Mas nem todas as narrativas nos jogos assumem a forma de conteúdo pré-gerado e incorporado. A narrativa também pode ser emergente, o que significa que ela surge a partir do conjunto de regras que regem a interação com o sistema de jogo. Ao contrário da narrativa incorporada, os elementos narrativos emergentes surgem durante o jogo a partir do sistema complexo do jogo, muitas vezes de formas inesperadas. Grande parte da ação narrativa momento a momento em um jogo é emergente, pois a escolha do jogador leva a experiências narrativas imprevisíveis. [...] A experiência narrativa exata de um determinado jogo [...] depende da interação do jogador. (SALEN; ZIMMERMAN, 2012b, p. 105).
\end{abstract}

Uma das muitas formas que os games utilizam para buscar inovação e uma, digamos, "voz própria" em relação à narrativa é a ficção não linear, ou o que Espen Aarseth (1997, 2 $2^{\underline{a}}$ capa) chama de literatura ergódica (ergodic literature): "um termo emprestado da física para descrever textos abertos e dinâmicos [...] com os quais o leitor deve realizar ações específicas para gerar uma sequência literária". ${ }^{20}$

Aarseth estabelece uma diferença primordial entre a literatura ergódica e a literatura "tradicional", que é o modo de leitura não trivial, que requer novas formas de lidar com um texto literário:

Na literatura ergódica, um esforço não trivial é necessário para permitir que o leitor percorra o texto. Para que a literatura ergódica faça sentido como conceito, também deve haver literatura não-ergódica, na qual o esforço para percorrer o texto é trivial, sem responsabilidades extranoemáticas ${ }^{21}$ colocadas sobre o leitor, a não ser, por

\footnotetext{
20 "[...] a term borrowed from physics to describe open, dynamic texts [...] with which the reader must perform specific actions to generate a literary sequence."

${ }^{21}$ Noemático é relativo à noema, que pode ser: 1) produto da inteligência; ideia, concepção, pensamento; ou 2) na fenomenologia husserliana, o objeto visado pela consciência humana (HOUAISS, 2009, verbete "noema"). Portanto, extranoemático pode ser interpretado como algo que ocorre fora dos limites do pensamento humano.
} 
exemplo, o movimento dos olhos e o virar periódico ou arbitrário de páginas. ${ }^{22}$ (AARSETH, 1997, p. 1-2).

Neste tipo de história que requer a interação com o jogador - e que, por conta desta interatividade, é uma narrativa não linear -, elevam-se muito as possibilidades narrativas nos videogames, e deixar de explorar esse potencial é como não aprender a manejar corretamente uma ferramenta à disposição do designer de jogos ou do roteirista. Conforme defende David Cage (roteirista de games narrativos como Heavy Rain, 2010, Beyond: Two Souls, 2013, e Detroit: Become Human, 2018),

Enquanto um roteirista linear precisa lidar com o tempo e o espaço, como roteirista interativo, preciso lidar com o tempo, o espaço e as possibilidades. Tenho que administrar enormes estruturas em árvore [estruturas ramificadas], em que cada galho é uma nova variação da história. Preciso pensar em todas as possibilidades de uma determinada cena e tentar imaginar tudo o que pode acontecer. Preciso lidar com milhares e milhares de variáveis, condições e possibilidades. [...] Mas acho que, no final das contas, a experiência é muito única, porque é o resultado da colaboração entre um roteirista que cria essa paisagem narrativa e o jogador que toma suas próprias decisões, contando sua própria história e tornando-se coautor e também o coator e o codiretor da história. ${ }^{23}$ (CAGE, 2018, 6m10s).

\section{Som nos videogames}

No início, por conta das restrições tecnológicas, os videogames contavam apenas com meros beeps e boops (efeitos sonoros rudimentares, de baixa qualidade) para criar alguma referência sonora ou melodias singelas, mas "Mesmo com as limitações, os criadores de jogos foram capazes de elaborar alguns temas musicais simples, mas memoráveis (ou mesmo apenas jingles) para jogos como Pac-Man, Donkey Kong e Legend of Zelda" (ROGERS, 2012, p. 400), temas esses que, apesar de não trazerem quaisquer diferenciais musicais, foram criativos diante das limitações tecnológicas que acabaram por direcionar as decisões sobre o material musical. Ou seja, a criatividade precisava driblar a falta de recursos. O que importa é ter em mente que o áudio faz parte da linguagem dos videogames praticamente desde seu surgimento. Antes disso, como já vimos, os games ainda não haviam constituído sua linguagem e eram apenas simulações eletrônicas de jogos de tabuleiro ou de mesa, criados

\footnotetext{
22 "In ergodic literature, nontrivial effort is required to allow the reader to traverse the text. If ergodic literature is to make sense as a concept, there must also be nonergodic literature, where the effort to traverse the text is trivial, with no extranoematic responsibilities placed on the reader except (for example) eye movement and the periodic or arbitrary turning of pages."

23 "Where a linear writer needs to deal with time and space, as an interactive writer, I need to deal with time, space and possibilities. I have to manage massive tree structures, where each branch is a new variation of the story. I need to think about all the possibilities in a given scene and try to imagine everything that can happen. I need to deal with thousands and thousands of variables, conditions and possibilities. [...] But I think, in the end, the experience is very unique, because it is the result of the collaboration between a writer creating this narrative landscape and the player making his own decisions, telling his own story and becoming the cowriter but also the coactor and the codirector of the story."
} 
praticamente como experimentos por profissionais da então incipiente área da informática. Mas logo se percebeu que, nos games, "A música pode intensificar a excitação da ação, avisar o jogador quando há algum perigo à frente ou criar uma atmosfera mais leve nos momentos cômicos" (NOVAK, 2010, p. 284). Assim, pouco após sua gênese, quando ainda não possuíam sons, os videogames se tornaram uma mídia audiovisual.

Desde os primórdios da utilização de som nos games, sempre foi uma constante o uso de músicas e efeitos sonoros eletroacústicos, inicialmente porque os games não possuíam capacidade de processamento e armazenamento suficientes para o emprego de faixas de áudios de alta fidelidade gravadas em estúdio, e assim, recorria-se aos sons de baixa fidelidade - os já mencionados beeps e boops. Isso, inclusive, tornou-se tão característico nos games a ponto de constituir-se parte de sua estética (seus constituintes visuais e sonoros, seus aspectos da realidade sensorial), e até hoje muitos games simulam os áudios de 8 ou 16 bits dos consoles antigos para remeter àquela antiga estética, hoje chamada de "retrô". ${ }^{24}$

Com o surgimento e a evolução dos hardwares e softwares utilizados para composição musical e síntese sonora, abriu-se um vasto campo de possibilidades para os games, que agora podiam recorrer ao áudio de alta fidelidade a custos relativamente baixos, ao contrário do que acontece, por exemplo, com a gravação de uma banda ou orquestra ou então com os equipamentos e produção de foley, ${ }^{25}$ muito mais usuais em grandes produções - chamadas de AAA (triple A) - com orçamentos suntuosos.

Sendo assim, o áudio para games é um rico campo de estudos para a sonologia, já que abarca diversos aspectos de interesse desse campo de estudos:

As novas músicas, feitas com novos instrumentos, observadas com novas teorias e escutadas com novos ouvidos: este é o objeto da sonologia. O termo, já utilizado em outras partes do mundo, sempre esteve conectado a uma concepção musical cujas práticas se avizinhavam das ciências e da tecnologia. Remete a uma música que incorpora as mídias e os artefatos da era eletrônica, os conhecimentos da acústica e psicoacústica, as ferramentas lógicas de auxílio à criação aliadas ao artesanato característico dos afazeres mais tradicionais. (IAZZETTA, 2008, p. 7).

Por ora, faremos uso da teoria da narrativa para definir como o áudio se comporta nos games. A partir do conceito de diegese ${ }^{26}$ proposto por Gérard Genette em Figures III (1972) e depois atualizado em Nouveau discours du récit (1983), pode-se estabelecer que, assim como no cinema, os sons podem assumir três tipos de papéis nos games: 1) diegético: quando os sons estão presentes no universo ficcional, ou seja, em sua diegese, e são ouvidos tanto pelo jogador quanto pelos personagens; 2) não diegético ou extradiegético: sons que são

\footnotetext{
${ }^{24}$ Ver: https://dicionario.priberam.org/retr\%C3\%B4 e www.significados.com.br/retro/.

25 "Áudio foley é a gravação ao vivo de efeitos sonoros - efeitos que você cria, captura e adiciona a programas de vídeo na pós-produção" (STINSON, s.d.; tradução livre).

${ }^{26}$ Diegese: o universo espacial-temporal no qual se desenrola a história (REIS; LOPES, 1988, p. 26).
} 
ouvidos pelo jogador, mas não estão presentes no universo ficcional, e consequentemente não são ouvidos pelos personagens; 3) metadiegético: sons subjetivos que fazem parte apenas da imaginação, sonho, visão, fantasia de um personagem ou de uma narração ou aparecem em flashback (GORBMAN, 1987).

Como já enfatizamos, há distinções na maneira como o áudio se comporta nos games e no cinema. Portanto, nada mais natural que surjam novos conceitos para a análise do áudio para games. Além das três definições genettianas apresentadas, há também o conceito de som transdiegético, cunhado por Kristine Jørgensen, cuja função é gerar feedback de alguma interação entre o jogador e o sistema do game:

[...] sons transdiegéticos não podem ser postulados claramente como diegéticos ou extradiegéticos. Eles se colocam em algum lugar entre ambos, seja por serem sons virtualmente extradiegéticos (que se comunicam com entidades internas à diegese, normalmente o avatar. Exemplo: música extradiegética que alerta sobre perigos iminentes) e também sons diegéticos (que se dirigem diretamente a entidades externas à diegese, normalmente o jogador. Exemplo: quando uma unidade em um game de estratégia diz "Tudo bem" quando o jogador Ihe dá uma ordem). Esses tipos de sons são centrais para a compreensão do posicionamento do som nos espaços dos games e funcionam como uma ponte entre o mundo do game e o mundo do jogador. Nesse sentido, esses sons se tornam parte da interface e permitem que ela se torne mais transparente..$^{27}$ (JØRGENSEN, 2007, p. 3).

A interatividade onipresente nos games, e ausente no cinema, promove novas possibilidades na utilização do áudio, assim como ocorre com a narrativa, conforme exposto anteriormente. E por se tratar de uma mídia audiovisual, é natural que os games façam uso de sons com propósitos variados, como: contribuir para a construção estética do jogo, fornecer informações, viabilizar a comunicação entre jogadores, apoiar o realismo imagético (um cenário realista, por exemplo, perde sua verossimilhança se os sons não forem igualmente realistas. Imagine um game com uma caracterização realista da cidade de São Paulo com os áudios de ambiência e efeitos sonoros semelhantes aos dos desenhos animados cômicos ou dos videogames de 8 bits) e proporcionar maior imersão.

Sons ambientes e efeitos sonoros possuem uma função muito importante em um game para a criação do cenário e seu consequente poder de imersão. Porém, a relação do áudio com o jogador se dá de maneira um pouco inusitada, pois quando bem-feitos e bem concatenados com o mundo ficcional, os efeitos sonoros podem até passar despercebidos,

\footnotetext{
27 "Such sounds will be defined as transdiegetic sounds, and what is characteristic for these is that they cannot be posited as clearly diegetic or extradiegetic. Instead, they seem in some respect to place themselves somewhere between the two, either by being virtually extradiegetic sounds that communicate to entities internal to the diegesis (typically the avatar, for example extradiegetic music that alerts about upcoming dangers), or they are diegetic sounds that directly address entities external to the diegesis (typically the player, for example when a strategy game unit says "all right" when the player gives it an order). These sounds are central for the comprehension of the positioning of sound in computer game spaces, and work as a bridge between the game world and the player's world. In this respect, these sounds become part of the interface, and enable the interface to become more transparent."
} 
mas quando estão em desarmonia com a ambientação, esses sons acabam sendo inconvenientemente notados por causar estranhamento, o que prejudica a imersão e a compreensão, principalmente, do jogador. De acordo com Novak,

Embora os elementos gráficos atraiam o jogador para a cena, o áudio exerce um efeito imersivo sobre o jogador que raramente é obtido somente com gráficos. Isso se deve, em parte, ao fato de que os sons da vida real são reproduzidos com muito mais fidelidade em um computador do que os elementos visuais. [...] Por causa do tamanho limitado da tela, em tese os jogadores podem se sentir alheios ao mundo visual do game. Em contraste, os jogadores podem ser envolvidos pelos sons do mundo de um game, que podem vir de todas as direções. (NOVAK, 2010, p. 272).

Algumas técnicas cinematográficas de áudio são utilizadas para intensificar a força dramática de um game (MURRAY, 2003, p. 63). Os efeitos sonoros de ambiências e de objetos, por exemplo, reforçam a realidade dos mundos imaginários. Mas nos games, os efeitos sonoros possuem o diferencial de fornecer orientações e indicações ao jogador, como sons de passos quando um inimigo oculto se aproxima, e também fornecem feedback, quando são baseados em eventos desencadeados por ações do jogador ou dos demais personagens do jogo (NOVAK, 2010, p. 277). Efeitos sonoros que são causados por eventos são uma forma sofisticada e sutil de indicar que o mundo ficcional está funcionando como devia e que as ações do jogador estão sendo bem-sucedidas (SCHUYTEMA, 2013, p. 185), o que contribui para a imersão do jogador, conforme afirma Schuytema:

A imersão do jogador é incrementada por efeitos orientados por eventos, pois enviam ao jogador uma mensagem de que suas ações podem afetar o mundo. Isso puxa o jogador mais para o interior do game e cria nele um sentimento muito importante de poder - ele pode ouvir que o que faz importa. As ações do jogador têm significado e servem para elevar o sentimento de poder e urgência no game. (SCHUYTEMA, 2013, p. 18).

Efeitos sonoros também são "eficazes para evocar um sentimento ou emoção no jogador, mas isso está mais ligado à interpretação do próprio jogador sobre o efeito sonoro (e o contexto do game), e não ao efeito sonoro em si" (SCHUYTEMA, 2013, p. 184).

As ambiências são muito adequadas para dar textura auditiva ao jogador e criar uma atmosfera realista (MURRAY, 2003, p. 63; SCHUYTEMA, 2013, p. 184). Essas texturas são percebidas passivamente pelo jogador, ou seja, elas acabam passando despercebidas, sem que o jogador esteja diretamente consciente desses efeitos, e isso ocorre justamente porque 0 jogador está imerso naquele universo ficcional, como se ele fosse real, verossímil, ${ }^{28}$ e sem essas texturas, a profundidade desse mundo virtual seria prejudicada. Elas contribuem para a

\footnotetext{
${ }^{28}$ Verossimilhança: "ligação, nexo ou harmonia entre fatos, ideias etc. numa obra literária, ainda que os elementos imaginosos ou fantásticos sejam determinantes no texto; coerência" (HOUAISS, 2009, verbete "verossimilhança").
} 
imersão do jogador e para a consequente suspensão da descrença (SCHUYTEMA, 2013, p. 184-185).

A suspensão da descrença se dá quando o jogador acolhe a realidade ficcional do jogo a tal ponto que "esquece" do mundo real e passa a "viver" dentro do mundo do game. Mesmo que as regras e experiências daquele mundo sejam impossíveis ou não façam sentido em nossa realidade, elas são aceitas pelo jogador e a história contada se torna mais vívida (NOVAK, 2010, p. 136). Mas para que isso ocorra, é necessário que a história seja verossímil, mesmo que as situações, personagens, lugares, objetos etc. sejam absurdos no mundo real. Portanto, suspensão da descrença, verossimilhança e imersão são conceitos intimamente conectados, conforme aponta Murray:

\begin{abstract}
Quando entramos num mundo ficcional, fazemos mais do que apenas "suspender" uma faculdade crítica; também exercemos uma faculdade criativa. Não suspendemos nossas dúvidas tanto quanto criamos ativamente uma crença. Por causa de nosso desejo de vivenciar a imersão, concentramos nossa atenção no mundo que nos envolve e usamos nossa inteligência mais para reforçar do que para questionar a veracidade da experiência. (MURRAY, 2003, p. 111).
\end{abstract}

Tanto os efeitos sonoros quanto as ambiências são fundamentais para a construção da paisagem sonora ${ }^{29}$ de um game. Quanto mais rica e detalhada for essa paisagem sonora, mais realista (no sentido de factível, e não no sentido de simulação do real, já que esses sons podem representar um mundo completamente fantástico) e imersiva ela será, oferecendo a sensação de que aquele mundo ou ambiente realmente existe e que o jogador realmente está dentro dele. "O que o analista da paisagem sonora precisa fazer, em primeiro lugar, é descobrir os seus aspectos significativos, aqueles sons que são importantes por causa de sua individualidade, quantidade ou preponderância" (SCHAFER, 2001, p. 25).

Especificamente nos videogames, a paisagem sonora pode ser subdividida em tópica, quando os sons são atribuídos a elementos gráficos, ou atópica, sons cujas fontes sonoras são imprecisas (CAMARGO, 2018, p. 63).

Há também os sons de falas: a narração é a voz do narrador (o conceito de narrador conforme apresentado na seção Narrativa nos videogames), que é quem transmite a história e faz a mediação entre ela e o jogador, e pode ou não ser um personagem da narrativa; e os diálogos, a interação verbal entre dois ou mais indivíduos, o conjunto das palavras trocadas pelos personagens (HOUAISS, 2009, verbete "diálogo").

\footnotetext{
${ }^{29}$ Conceito popularizado por R. Murray Schafer (2001, p. 24): "Uma paisagem sonora consiste em eventos ouvidos e não em objetos vistos", e pode ser dividida em: sons fundamentais, as notas que identificam a escala ou tonalidade de uma música ou os sons criados pela geografia e pelo clima (água, vento, pássaros, insetos, animais); sinais, sons destacados e ouvidos conscientemente como recursos de avisos acústicos (sinos, apitos, buzinas, sirenes); e marcas sonoras, sons únicos de uma comunidade, que possuem certas qualidades que os tornam especialmente significativos ou notados pelas pessoas daquele lugar (derretimento de geleiras, vulcões em erupção, campos de enxofre fervente).
} 
E além de ambiências e efeitos sonoros no áudio de um game, há também a música. Ela pode fornecer pistas acerca da direção e das decisões tomadas pelo jogador, de forma semelhante às dicas de "quente" e "frio" nas brincadeiras de caça ao tesouro, e com isso transformar uma descoberta simples em um momento de revelação (MURRAY, 2003, p. 63), reforçando a carga dramática proposta pelo game.

Assim como ocorre no cinema, a música confere grande carga emocional ao game, e reforça a dramaticidade decorrente das experiências de jogo. Ela é responsável por criar atmosferas e envolver emocionalmente o jogador, ao enfatizar certas áreas, locais e situações, muitas vezes baseadas em convenções de gêneros (como o uso de percussões na iminência de um ataque tribal ou repetições de intervalos dissonantes em uma cena de suspense) ou tradições culturais. Esse potencial da música em despertar ou induzir determinados estados afetivos tem o poder de influenciar indiretamente o comportamento do jogador. Ao deixá-lo ansioso, por exemplo, o jogador pode se tornar mais cauteloso para evitar surpresas desagradáveis. Quando o jogador fica ansioso, ele pode agir com mais cuidado para evitar quaisquer inimigos perigosos e situações desagradáveis (JØRGENSEN, 2006, p. 3).

As músicas podem ser compostas especificamente para o game ou então serem licenciadas para uso no game (músicas que foram produzidas e lançadas antes da existência do game e que não tinham ligação com este).

Um uso comum das músicas nos games é nas transições entre cenas, menus e cutscenes (também chamadas de cinematics, que são pequenos filmes narrativos e não interativos geralmente exibidos no início e no fim dos níveis e do game), para atenuar os cortes da narrativa ou unir partes, tornando menos abruptos esses momentos de transições e de pausas (CAMARGO, 2018, p. 122). A música, ou a sua interrupção, também pode servir para indicar o início ou o fim de uma fase ou de alguma parte específica do jogo (COLLINS, 2008, p. 131).

Um dos desafios em criar áudio para games ocorre em função da não linearidade da narrativa. Por conta dessa característica, não é possível saber com precisão quando um som será tocado, em qual momento específico, já que o andamento do jogo e da narrativa acontece por conta das decisões do jogador, e não exatamente pelo que foi estabelecido pelo designer de jogos ou pelo roteirista (SNYDER, Scott apud NOVAK, 2010, p. 281). No cinema, ao contrário, cada som ocorre exatamente sempre no mesmo momento, mesmo que o filme seja assistido diversas vezes. Cada cena, cada efeito sonoro, cada música, cada diálogo ocorrerá sempre no mesmo momento da sucessão linear da narrativa. Já nos games, cada vez que um game é jogado, a sucessão de fatos pode se alterar, conforme as decisões tomadas pelo jogador em cada vez que ele joga o game, principalmente quando a narrativa é do tipo ramificada, em que a sucessão de acontecimentos depende das decisões tomadas pelo jogador. Neste caso, cada decisão pode levar a um tipo diferente de sucessão de fatos, já que, em um ambiente interativo, é difícil - para 
não dizer impossível - prever quando e como o jogador irá interagir com o ambiente, com os objetos e personagens. Esta é a natureza não linear de um game.

Portanto, o design e a composição da trilha sonora de um game se dão de maneira diferente de como são realizados para o cinema. É para dar conta dessa especificidade que existe o áudio dinâmico, uma técnica utilizada para que os sons tenham reações específicas de acordo com o estado da interface, com as mudanças no ambiente e com as ações do jogador. O áudio responde de forma automatizada de acordo com certos parâmetros, como localização espacial, condição narrativa, estados de alerta etc. Ou seja, o áudio, além de responder às ações do jogador (por exemplo, quando o personagem pula, ataca, corre ou pega um item), também responde a outras variáveis, que são do próprio sistema do game e ocorrem sem o controle direto do jogador (contagem de tempo, performance, proximidade de um determinado local, nível de vitalidade etc.) (CARVALHO; PEREIRA, 2017).

Em relação à música utilizada como áudio dinâmico, é possível encará-la em termos de estrutura vertical e horizontal:

A estrutura vertical descreve a instrumentação, o arranjo e a mixagem da música, às vezes, descritos como a densidade ou intensidade da cena do game. Conforme o jogador entra e sai de situações, a capacidade dessa qualidade de acompanhar o estado do game é muito eficaz. No eixo horizontal, consideramos a disposição dos segmentos musicais ou o sequenciamento do desenvolvimento musical. (JAVELOSA, David apud NOVAK, 2010, p. 293-294, grifo nosso).

Assim, é possível, por exemplo, compor uma música em "camadas", sendo que em cada camada há um instrumento ou um conjunto de instrumentos. Em uma situação hipotética, digamos que uma música é composta pelas seguintes camadas (que juntas formam um arranjo musical completo): 1) piano, 2) violino, 3) violoncelo e 4) percussão. Enquanto o personagem do jogador (que chamaremos aqui de player) caminha livremente pelo mundo ficcional do game, está em execução apenas a camada 1. Quando o player chega a uma determinada distância da tribo inimiga, a camada 2 passar a ser executada junto com a 1 (se o player sai do raio de distância estabelecido no parâmetro da programação, somente a camada 1 volta a ser executada). No momento em que os inimigos notam a presença do player, entra em execução também a camada 3. Se a distância entre o player e os inimigos se torna ainda mais próxima, passam a ser executadas somente as camadas 3 e 4 , indicando que a batalha é iminente.

\section{Do videogame ao audiogame}

Audiogames são jogos eletrônicos cujo conteúdo é transmitido por meio do som, integral ou predominantemente, e podem ser subdivididos em duas categorias: os audio-only-games (AOGs) são aqueles que não fazem quaisquer usos de recursos visuais, enquanto os audio- 
based-games (ABGs) contêm alguns elementos visuais como suporte para facilitar a percepção dos estímulos auditivos (ROVITHIS; MNIESTRIS; FLOROS, 2014, p. 1). Em ambos os casos, as informações são transmitidas principalmente ou exclusivamente por sons. Os jogadores precisam se concentrar na audição para interagir com o sistema do jogo, o que inclui percorrer o espaço virtual do jogo, compreender e executar as ações necessárias e interpretar feedbacks (ROVITHIS; FLOROS; KOTSIRA, p. 497).

Audiogames geralmente são baseados em narrativas, abarcam diversos tipos de gêneros de games (aventura, ação, corrida, quebra-cabeça etc.) e muitos são desenvolvidos com propósitos experimentais, de aprendizagem (amadores que estão aprendendo a desenvolver games) ou de acessibilidade a deficientes visuais.

Por não conter elementos visuais, ou um número muito limitado deles, é natural que a paisagem sonora tenha grande relevância nos audiogames, já que ela é um dos recursos para a construção do universo ficcional do jogo, em conjunto com as descrições, a narração e os diálogos. Portanto, é nítido que a percepção sonora e a habilidade de ouvir são fundamentais. Por conta dessa imersão em um ambiente puramente sônico e de uma experiência de jogo alternativa, além das novas tecnologias em dispositivos móveis, tem crescido o interesse pelos audiogames, já que eles são propícios para diversos públicos de jogadores (ROVITHIS, 2012, p. 160), como jogadores casuais, jogadores de RPGs e demais jogos narrativos, pessoas em fase de aprendizagem musical, deficientes visuais e até mesmo hard gamers (jogadores que costumam jogar por várias horas e com bastante frequência) em busca de novas experiências em games. Ademais, profissionais de áudio para games têm se interessado cada vez mais pelos audiogames por conta de suas possibilidades de experimentação, do envolvimento direto desses profissionais com a programação do game e dos constantes avanços das técnicas e tecnologias em áudio, como o áudio dinâmico e o áudio binaural. ${ }^{30}$

A redução ou total exclusão de informações visuais pode potencializar a aquisição de certas habilidades, como o aumento da memória e a capacidade de concentração, e podem introduzir qualquer pessoa, músico ou não músico, aos conceitos e princípios musicais e de estudos do som (ROVITHIS; MNIESTRIS; FLOROS, 2014, p. 1), o que é um rico campo de estudos e aplicações para a área da cognição musical.

Por fim, é possível classificar os audiogames quanto ao seu modo de operação de áudio (PARKER; HEEREMA, 2008):

- Rememoração de padrões: o jogador deve memorizar padrões específicos

de sons, tonais ou rítmicos.

\footnotetext{
30 Ver: https://www.tecmundo.com.br/fone-de-ouvido/11683-audio-binaural-efeito-3d-em-fones-de-ouvidoestereo.htm e https://www.theverge.com/2015/2/12/8021733/3d-audio-3dio-binaural-immersive-vr-sound-timessquare-new-york.
} 
- Áudio posicional: uso de áudio posicional para navegação ou interação com objetos dispostos no ambiente virtual 3D do game.

- Input por comando de voz: uso de reconhecimento de linguagem falada simples. $O$ game é projetado para reconhecer determinadas respostas específicas, e não falas livres.

- Ritmo de sincronização: sincronizar o ritmo com outras atividades.

- Input de som relacional a uma música: uso de qualidades tonais de entrada de som como uma combinação para uma peça musical existente.

- Interação por meio de gestos: uso de gestos específicos do mouse, touch pad ou tela sensível ao toque para criar vinhetas musicais e sons.

- Controle por movimentos: uso de gestos e movimentos humanos para controlar sons e música por meio de sensores de movimento.

\section{Conclusões}

Neste artigo, tomamos como postulado o que talvez seja a mais relevante diferença entre a linguagem verbal e a música: a semântica. Dentre outras características, a linguagem é constituída de semântica, enquanto a música não possui semântica, ${ }^{31}$ a não ser em um nível metafórico, subjetivo (BORGES NETO, 2005). A semântica é uma das partes constituintes da linguagem, portanto, sem semântica, sem significado, não há linguagem. Ou seja, se a música não possui semântica, então ela é uma forma de comunicação puramente expressiva, que não possui signos linguísticos. ${ }^{32}$ Um dos propósitos da música nos games, de grande relevância para o presente estudo, é o de evocar emoções e sugerir sentimentos (FORNARI, 2019a).

Diante disso, podemos definir que os efeitos sonoros em um game se distanciam da música - ainda que ambos sejam constituídos por sons - por terem função mais objetiva (em contraponto a expressivo) e carregarem significados específicos, como um som de explosão, que denota uma bomba, e não uma flor ou um beijo (nesses casos, o emprego do efeito sonoro de uma bomba carregaria conteúdo subjetivo e metafórico, portanto, expressivo).

Conclui-se, então, que os jogos eletrônicos se utilizam de comunicação semântica (narrações e diálogos textuais ou verbais) e de signos $^{33}$ visuais (imagens, textos, símbolos,

\footnotetext{
${ }^{31}$ Leonard Bernstein (The Unanswered Question: Lecture 3, "Musical Semantics", 1973) chegou a apresentar uma possível estrutura semântica para a música, com base na gramática universal de Noam Chomsky. Porém, o próprio autor admitiu tratar-se apenas de uma teoria especulativa, sem embasamento teórico formal (FORNARI, 2019b; 2019c).

${ }^{32} \mathrm{Na}$ tradição saussureana, um signo linguístico é a união entre um significado (conceito, conteúdo) e um significante (imagem acústica, forma), ou seja, é um símbolo, índice ou sinal indicativo que, por convenção, carrega um conceito/significado (DUBOIS et al., 2004).

${ }^{33}$ Para a semiótica, um signo se constitui em "uma unidade do plano da manifestação constituída pela [...] relação de pressuposição recíproca que se estabelece entre grandezas do plano da expressão (do significante) e do plano do conteúdo (do significado) no momento do ato da linguagem" (GREIMAS; COURTÉS, 2008, p. 462).
} 
ícones, sinais etc.) e sonoros (paisagem sonora, efeitos sonoros) para fornecer informações objetivas a respeito do universo ficcional, da narrativa e do gameplay, enquanto que a música é responsável por fornecer, ou sugerir, informações subjetivas, ou seja, evocar sentimentos e gerar sensações tanto para informar o jogador quanto para induzir determinados comportamentos.

Como os games possuem particularidades (interatividade, não linearidade), é natural ou pelo menos desejável - que tais recursos semânticos e não semânticos sejam utilizados de formas inovadoras em relação a outras mídias, com a intenção de explorar todo o potencial dos games e fornecer experiências únicas e significativas aos jogadores. Assim, advogamos que imagens, sons, narrativa e jogabilidade sejam utilizados de forma sinérgica para que os games atinjam seu máximo potencial expressivo, comunicativo e lúdico, sem que haja prevalência de uma dessas formas de comunicação pelas outras (como é o caso da quase onipresença do apelo visual) por conta de questões mercadológicas, que visam apenas o lucro e preterem os aspectos artísticos de um game.

Se os sons em um game são de suma importância para a imersão do jogador, para a criação de universos ficcionais ricos e verossímeis, para a comunicação expressiva, para evocar emoções e para a construção e desenvolvimento da narrativa, não há razões para que música e efeitos sonoros sejam tratados apenas como cosméticos ou ornamentos, deixando mais tempo para a criação de aspectos visuais mais elaborados.

E se a narrativa - atividade humana central, uma experiência liminar - é preponderante para a imersão, para o engajamento, para a coautoria do jogador e para a criação de experiências lúdicas significativas, é incongruente não lhe dar a devida atenção (a não ser em casos específicos, como o de jogos puramente abstratos) por acreditar que outros aspectos do game merecem maior relevância.

Games são mídias multilinguagens, e é sob esse aspecto que devem ser tratados, caso contrário, se somente um de seus elementos constituintes for privilegiado, corre-se o risco de prolongar a sua fase de amadurecimento enquanto expressão comunicativa, artística, narrativa, musical, educacional e lúdica. No mínimo, a primazia da visão nos videogames incorre ao erro de enfatizar a visão em detrimento dos outros sentidos.

\section{Referências}

AARSETH, Espen J. Cybertext: perspectives on ergodic literature. Baltimore: The Johns Hopkins University Press, 1997.

ADORNO, Theodor W. Indústria cultural e sociedade. São Paulo: Paz e Terra, 2002.

AGUIAR, Michelle; BATTAIOLA, André Luiz. Gameplay: uma definição consensual à luz da literatura. In: SBGAMES, 15., set. 2016, São Paulo. Anais...: Art \& Design Track, São Paulo: SBC, 2016, p. 531-538. Disponível em: http://www.sbgames. org/sbgames2016/downloads/anais/157561.pdf. Acesso em: 14 jul. 2021. 
ARCADE game. In: TECHOPEDIA. [S.I.]: Janalta Interactive, 2021. Disponível em: www.techopedia.com/definition/1903/arcade-game. Acesso em: 8 fev. 2021.

BAUDRILLARD, Jean. Simulacros e simulação. Lisboa: Relógio d'Água, 1991.

BORGES NETO, José. Música é linguagem? Revista Eletrônica de Musicologia, Curitiba: UFPR, v. IX, out. 2005. Disponível em: http://www.rem.ufpr.br/_REM/REMv9-1/borges.html. Acesso em: 9 mar. 2021.

CAGE, David. How video games turn players into storytellers. TED Talks, abr. 2018. Disponível em: https://www.ted.com/talks/david_cage_how_video_games_turn_players_into_storytellers. Acesso em: 15 fev. 2021.

CAMARGO, Fernando Emboaba de. Interatividade e narratividade sonora nos games. Campinas, 2018. 188 f. Tese (Doutorado em Música) - Instituto de Artes, Universidade Estadual de Campinas.

CAMPBELL, Joseph. O herói de mil faces. 11. ed. São Paulo: Cultrix/Pensamento, 1995.

CARVALHO, Luiz Roberto; PEREIRA, Alice T. Cybis. Áudio dinâmico: o design de som nos ambientes interativos. Ergodesign e $\mathrm{HCl}$, Rio de Janeiro, n. especial, v. 5, a. 5, 2017.

COLLINS, Karen. Game sound: an introduction to the history, theory, and practice of video game music and sound design. Cambridge, USA; London, UK: MIT Press, 2008.

CONSOLE game. In: TECHOPEDIA. [S.I.]: Janalta Interactive, 2021. Disponível em: https://www.techopedia.com/definition/756/console-game. Acesso em: 8 fev. 2021.

DEBORD, Guy. A sociedade do espetáculo. Rio de Janeiro: Contraponto, 1997.

DUBOIS, Jean et al. Dicionário de linguística. 9. ed. São Paulo: Cultrix, 2004.

ESPOSITO, Nicolas. A short and simple definition of what a videogame is. In: DiGRA INTERNATIONAL CONFERENCE: Changing Views: Worlds in Play, 2005, Vancouver. Anais... Vancouver, Canada: DiGRA 2005, 16-20 jun. 2005. Disponível em: http://www.digra.org/digital-library/publications/a-shortand-simple-definition-of-what-a-videogame-is/. Acesso em: 5 fev. 2021.

FORNARI, José. Liberdade e significado musical. Musicologia na Mídia, Blogs de Ciência da Universidade Estadual de Campinas, 25 set. 2019a. Disponível em: www.blogs.unicamp.br/musicologia/2019/09/25/32/. Acesso em: 9 mar. 2021.

FORNARI, José. Modelos musicais de expectativa. Musicologia na Mídia, Blogs de Ciência da Universidade Estadual de Campinas, 20 fev. 2019b. Disponível em: www.blogs.unicamp.br/musicologia/2019/02/20/8/. Acesso em: 10 mar. 2021.

FORNARI, José. O compartilhamento de recursos cerebrais entre música e linguagem. Musicologia na Mídia, Blogs de Ciência da Universidade Estadual de Campinas, 31 jul. 2019c. Disponível em: www.blogs.unicamp.br/musicologia/2019/07/31/28/. Acesso em: 10 mar. 2021.

GAMEPAD. In: TECHOPEDIA. [S.I.]: Janalta Interactive, 2021. Disponível em: www.techopedia.com/definition/7363/gamepad. Acesso em: 8 fev. 2021.

GORBMAN, Claudia. Unheard melodies: narrative film music. Bloomington; Indianapolis: Indiana University Press; London: BFI Publishing, 1987.

GREIMAS, A. J.; COURTÉS, J. Dicionário de semiótica. São Paulo: Contexto, 2008.

HOUAISS, Antonio [Instituto]. Houaiss Eletrônico. Versão 3.0. Rio de Janeiro: Objetiva, 2009.

IAZZETTA, Fernando. Entre a pesquisa e a criação: a experiência dentro da sonologia. In:

CONGRESSO DA ANPPOM, XXIV., ago. 2014, São Paulo. Anais... São Paulo: ANPPOM, 2014.

Disponível em: https://anppom.com.br/congressos/index.

php/24anppom/SaoPaulo2014/paper/view/3014. Acesso em: 16 fev. 2021.

IAZZETTA, Fernando. Sonologia, uma tentativa de introdução. In: SEMINÁRIO MÚSICA CIÊNCIA TECNOLOGIA: Sonologia, 3., 2008, São Paulo. Anais... São Paulo: USP, 2008, p. 5-8. Disponível em: http://www2.eca.usp.br/smct/ojs/index.php/smct/ article/view/36/35. Acesso em: 26 fev. 2021. 
JOYSTICK. In: TECHOPEDIA. [S.I.]: Janalta Interactive, 2021. Disponível em: www.techopedia.com/definition/31108/joystick. Acesso em: 8 fev. 2021.

JØRGENSEN, Kristine. On the functional aspects of computer game audio. In: Proceedings of the Audio Mostly Conference, Interactive Institute, Piteå, Sweden, 2006. Disponível em:

http://hdl.handle.net/1956/6734. Acesso em: 1 mar. 2021.

JØRGENSEN, Kristine. On transdiegetic sounds in computer games. Northern Lights: Film and Media Studies Yearbook, Bristol: Intellect Press, v. 5, n. 1, set. 2007, p. 105-117. Disponível em:

http://hdl.handle.net/1956/5855. Acesso em: 12 fev. 2021.

JUUL, Jesper. Games Telling stories? A brief note on games and narratives. Game Studies: the international journal of computer game research, v. 1, n. 1, jul. 2001. Disponível em: http://www.gamestudies.org/0101/juul-gts/. Acesso em: 10 fev. 2021.

LUZ, Alan Richard da. Vídeo game: história, linguagem e expressão. São Paulo: Blucher, 2010. MARQUES, Maria Helena Duarte. Iniciação à semântica. 6. ed. Rio de Janeiro: Jorge Zahar, 2003.

MURRAY, Janet. From game-story to cyberdrama. Electronic Book Review, 1 mai. 2004. Disponível em: https://electronicbookreview.com/essay/from-game-story-to-cyberdrama/. Acesso em: 9 fev. 2021.

MURRAY, Janet. Hamlet no holodeck: o futuro da narrativa no ciberespaço. São Paulo: Itaú Cultural; Editora Unesp, 2003.

NOVAK, Jeannie. Desenvolvimento de games. São Paulo: Cengage Learning, 2010.

PARKER, J. R.; HEEREMA, John. Audio interaction in computer mediated games. International Journal of Computer Games Technology, v. 2008, Article ID 178923, 2008.

PINTO, Tiago de Oliveira. Som e música: questões de uma antropologia sonora. Revista de Antropologia, São Paulo, v. 44, n. 1, p. 221-286, 2001. Disponível em:

https://www.revistas.usp.br/ra/issue/view/2039. Acesso em: 16 fev. 2021.

REIS, Carlos. Dicionário de estudos narrativos. Coimbra: Almedina, 2018.

REIS, Carlos; LOPES, Ana Cristina M. Lopes. Dicionário de teoria da narrativa. São Paulo: Ática, 1988.

RODRIGUES, Gessica Palhares; PORTO, Cristiane de Magalhães. Realidade virtual: conceitos, evolução, dispositivos e aplicações. Interfaces Científicas: Educação, Aracaju, v. 1, n. 3, p. 97-109, jun. 2013. Disponível em: https://periodicos.set. edu.br/educacao/article/view/909/414. Acesso em: 16 fev. 2021.

ROGERS, Scott. Level up: um guia para o design de grandes jogos. São Paulo: Blucher, 2012.

ROVITHIS, Emmanouel. A classification of audio-based games in terms of sonic gameplay and the introduction of the audio-role-playing-game: Kronos. AM '12, Corfu, Greece, 26-28 set. 2012, p. 160-164.

ROVITHIS, Emmanouel; FLOROS, A.; KOTSIRA, L. Educational audio gamification: theory and practice. In: EUROPEAN CONFERENCE ON E-LEARNING (ECEL), 17., 2018. Anais... Atenas, v. 17, nov. 2018, p. 497-505.

ROVITHIS, Emmanouel; MNIESTRIS, A.; FLOROS, F. Educational audio game design: sonification of the curriculum through a role-playing scenario in the audio game 'Kronos'. In: AM 2014, out. 2014,

New York. Anais... Proceedings of the 9th Audio Mostly: A Conference on Interaction With Sound (AM '14). Association for Computing Machinery, New York, NY, USA, Article 21, p. 1-6.

SALEN, Katie; ZIMMERMAN, Eric. Regras do jogo: fundamentos do design de jogos: principais conceitos, v. 1. São Paulo: Blucher, 2012a.

SALEN, Katie; ZIMMERMAN, Eric. Regras do jogo: fundamentos do design de jogos: interação lúdica, v. 3. São Paulo: Blucher, 2012b.

SCHAFER, R. Murray. A afinação do mundo. São Paulo: Ed. Unesp, 2001. 
SCHELL, Jesse. A arte de game design: o livro original. Trad. Edson Furmankiewicz. Rio de Janeiro: Elsevier, 2011.

SCHUYTEMA, Paul. Design de games: uma abordagem prática. São Paulo: Cengage Learning, 2013.

STINSON, Jim. Real-time sound effects: the Foley way. Videomaker, [1 July 1999]. Disponível em:

https://www.videomaker.com/article/7220-real-time-sound-effects-the-foley-way. Acesso em: 3 mar. 2021. 